\title{
Modulation of Human T-type Calcium Channels by Synthetic Cannabinoid Receptor
}

\section{Agonists in vitro}

Chris Bladen ${ }^{1}$, Somayeh Mirlohi ${ }^{1}$, Marina Santiago ${ }^{1}$, Mitchell Longworth $^{2}$, Michael Kassiou ${ }^{2}$, Sam Banister ${ }^{2,3}$, Mark Connor ${ }^{1}$

Biomedical Sciences, Macquarie University, Sydney, NSW ${ }^{1}$, School of Chemistry ${ }^{2}$ and The Lambert Initiative for Cannabinoid Therapeutics ${ }^{3}$, University of Sydney, Sydney NSW 2006.

Corresponding Author: Chris Bladen. Department of Biomedical Sciences, Macquarie University, NSW, Australia. Phone:+61 29850 2708. Email: chris.bladen@mq.edu.au

Running Title: Synthetic cannabinoids modulate T-type channels

Author Contributions: CB designed, performed and analysed experiments and wrote the manuscript, SM performed and analysed experiments, MS created the cell lines and developed the calcium 5 assay used in FLIPR experiments, ML, MK and SB synthesised the synthetic cannabinoids, MC contributed to the design, analysis of experiments and writing of manuscript.

\begin{abstract}
BACKGROUND AND PURPOSE

Consumption of Synthetic Cannabinoid Receptor agonists (SCRAs) is associated with severe adverse reactions including seizures, arrhythmias and death, but the molecular mechanisms surrounding SCRA toxicity are not yet established. These disease-like symptoms are also synonymous with altered T-type calcium channel activity which controls rhythmicity in the heart and brain. This study examined whether SCRAs alter T-type activity and whether this represents a possible mechanism of toxicity.
\end{abstract}




\section{EXPERIMENTAL APPROACH}

Fluorescence-based and electrophysiology assays were used to screen 16 structurally related synthetic cannabinoids for their ability to inhibit human T-type calcium channels expressed in HEK293 cells. The most potent compounds were then further examined using patch clamp electrophysiology.

\section{KEY RESULTS}

MDMB-CHMICA and AMB-CHMINACA potently blocked Cav3.2 with IC50 values of 1.5 and $0.74 \mu \mathrm{M}$ respectively. Current inhibition increased from 47 to $80 \%$ and 45 to $87 \%$ respectively when the channel was in slow-inactivated state. Both SCRAs had little effect on steady state inactivation, however MDMB-CHMICA significantly shifted the half activation potential by $-7 \mathrm{mV}$. Neither drug produced frequency dependent block, in contrast to the phytocannabinoid $\triangle 9$-THC.

\section{CONCLUSIONS and IMPLICATIONS}

SCRAs are potent agonists of CB1 receptors and can be extremely toxic, but observed toxicity also resembles symptoms associated with altered Cav3.2 activity. Many SCRAs tested were potent modulators of Cav3.2, raising the possibility that SC toxicity may be due in part to Cav3.2 modulation. This potent T-type channel modulation suggests the possibility of SCRAs as a new drug class with potential to treat diseases associated with altered T-type channel activity.

KEY WORDS: T-type Calcium Channels, Synthetic Cannabinoids, Pain, Epilepsy, Electrophysiology, FLIPR assay, Toxicity.

\section{ABBREVIATIONS}


AEA: N-arachidonoylethanolamine

AHP: afterhyperpolarization

AMB-CHMINACA: methyl 2-((1-(cyclohexylmethyl)-1H-indazole-3-carbonyl)amino)-3methylbutanoate

$\mathrm{Ca}_{\mathrm{v}} 3 . \mathrm{x}$ : human low voltage-activated calcium channel 3.x

$[\mathrm{Ca}]_{\mathrm{i}:}$ intracellular calcium concentration

CB1: cannabinoid receptor type 1

CB2: cannabinoid receptor type 2

CBD: cannabidiol

Ephys: electrophysiology

FLIPR: Fluorescence Imaging Plate Reader

MDMB-CHMICA:

methyl-2-[[1-(cyclohexylmethyl)indole-3-carbonyl]amino]-3,3-

dimethylbutanoate

SC: synthetic cannabinoid

$\Delta^{9}$-THC: $\Delta^{9}$-tetrahydrocannabinol 


\section{Introduction}

The human genome includes three types of low-voltage-activated calcium channels (T-type $I_{\mathrm{Ca}}$ ); $\mathrm{Ca}_{\mathrm{v}} 3.1, \mathrm{Ca}_{\mathrm{v}} 3.2$ and $\mathrm{Ca}_{\mathrm{v}} 3.3$ and each have specific cellular functions. (Perez-Reyes 2003). One of their key properties is their ability to activate near the threshold of cellular resting membrane potential, allowing quick responses to subtle changes in electrical activity and to amplify depolarizations, but also to inhibit them via afterhyperpolarizations (AHPs) following $\mathrm{Ca}^{2}$ influx (Bender et al., 2012). In particular, the $\mathrm{Ca}_{\mathrm{v}} 3.2$ channel is thought to play a critical role in many physiological processes by using these characteristics to control and regulate rhythmicity in the heart and brain (Kampa, Letzkus et al. 2007, David, Garcia et al. 2010, Ono and Iijima 2010, Bender, Uebele et al. 2012). Conversely, several disease states including cardiac arrhythmia, epilepsy and pain (Khosravani, Bladen et al. 2005, Heron, Khosravani et al. 2007, Ono and Iijima 2010, Zamponi, Lory et al. 2010) have been attributed to aberrant $\mathrm{Ca}_{\mathrm{v}} 3.2$ activity. Indeed in pain, up-regulation of $\mathrm{Ca}_{\mathrm{v}} 3.2$ has been linked to hyper-excitability of primary afferent fibers in chronic pain disorders, while animals with $\mathrm{Ca}_{\mathrm{v}} 3.2$ knocked out have shown dramatically reduced nociception in formalin assays of acute and inflammatory pain (Bourinet, Alloui et al. 2005, Choi, Na et al. 2007, Jagodic, Pathirathna et al. 2008, Bladen, McDaniel et al. 2015).

Synthetic Cannabinoid Receptor agonists (SCRAs) are a large class of drugs whose unregulated use and consumption in part aims to mimic the effects of $\Delta^{9}$-tetrahydrocannabinol $\left(\Delta^{9}\right.$-THC), the principal psychoactive component of Cannabis (Banister and Connor 2018). However, some SCRAs are at least 300 times more efficacious at activating human cannabinoid (CB) receptor 1 when compared to $\Delta^{9}$-THC (Banister, Moir et al. 2015, Banister, Longworth et al. 2016, Sachdev, Vemuri et al. 2019). Not surprisingly, these highly potent drugs have been associated with many instances of hospitalization and even a significant number of deaths attributed to people consuming them (Banister, Longworth et al. 2016, Najafi, 
Dunn et al. 2016, Longworth, Connor et al. 2017). Although the adverse psychotomimetic effects seen in patients ingesting SCRAs are likely due to their interactions with CB receptors, it is less clear what causes the other severe adverse reactions such as abnormal heart rate, hyperalgesia and seizure activity (Trecki, Gerona et al. 2015, Najafi, Dunn et al. 2016, Tait, Caldicott et al. 2016, Babi, Robinson et al. 2017, EMCDDA 2017). In the library of SCRAs we tested for T-type channel activity in this report, two of the SC compounds MDMBCHMICA and AMB-CHMINACA, potently modulated T-type calcium channel conductance (T-type $I_{\mathrm{Ca}}$ ) in both a tonic and state-dependent manner. These two SCRAs have been identified as causing acute toxicity and death, yet they are not the most potent or efficacious activators of CB1 (Adamowicz 2016, Banister, Longworth et al. 2016, Najafi, Dunn et al. 2016, Sachdev, Vemuri et al. 2019).

To date, little is known about synthetic cannabinoid mechanisms of action beyond them being highly potent activators of cannabinoid receptors. This report has established that some synthetic cannabinoids also potently regulate and inhibit $\mathrm{Ca}_{\mathrm{v}} 3.2$, a calcium channel crucial to regulating heart and brain function. This modulation of a protein not traditionally thought of as a cannabinoid receptor not only adds to our basic understanding of synthetic cannabinoid interactions with human proteins, but it may point to an additional mechanism through which synthetic cannabinoids can cause acute toxicity in users.

\section{Methods}

\section{Transfection and Cell culture:}

All experiments were performed using HEK293 FLPIN T-REX cells stably transfected with pcDNA5/FRT/TO constructs encoding human $\mathrm{Ca}_{\mathrm{v}} 3 . \mathrm{x}$ cDNA as per Thermofisher protocol, (synthesized by Genscript,Piscataway, NJ, USA) together with pOG44 (Flp recombinase) plasmid using Fugene HD as per Promega protocol (Promega, Alexandria, NSW, Australia, 
Knapman et al., 2014a). Cells expressing the $\mathrm{Ca}_{\mathrm{v}} 3 . \mathrm{x}$ constructs were selected using $150 \mu \mathrm{g} / \mathrm{mL}$ hygromycin $+15 \mu \mathrm{g} / \mathrm{mL}$ blasticidin and cultured in DMEM supplemented with $10 \%$ FBS, 100 units/mL penicillin, $100 \mu \mathrm{g} / \mathrm{mL}$ streptomycin up until passage 5 . Hygromycin was then reduced to $80 \mu \mathrm{g}$ for subsequent passages. $\mathrm{Ca}_{\mathrm{v}} 3 . \mathrm{x}$ expression was induced $24 \mathrm{~h}$ before FLIPR assays or electrophysiology experiments by adding $2 \mu \mathrm{g} / \mathrm{mL}$ tetracycline. Cells were maintained and passaged at $80 \%$ confluency in $75-\mathrm{cm}^{2}$ flasks and kept at $37^{\circ} \mathrm{C} / 5 \% \mathrm{CO}_{2}$. Cells for FLIPR assays were grown in same conditions but used at $>90 \%$ confluence.

\section{Electrophysiology:}

All whole-cell voltage-clamp recordings from HEK293 FLPIN T-REX cells stably transfected with human $\mathrm{Ca}_{\mathrm{v}} 3 . \mathrm{x}$ were performed at room temperature. At least $24 \mathrm{~h}$ prior to experiments, cells were detached from flasks using trypsin/EDTA and plated into $10 \mathrm{~cm}$ sterile tissue culture dishes containing $10 \mathrm{~mL}$ of supplemented DMEM and 10-15 glass coverslips (12 mm diameter, ProScitech, QSLD, Australia). Culture dishes were then kept overnight in same conditions as flasks to allow cells to adhere to coverslips. They were then transferred to a $30^{\circ} \mathrm{C} / 5 \% \mathrm{CO}_{2}$ incubator to inhibit cell proliferation until ready to be used for electrophysiology experiments.

\section{Recording solutions:}

External recording solutions contained (in mM): $114 \mathrm{CsCl}, 5 \mathrm{BaCl}_{2}, 1 \mathrm{MgCl}_{2}, 10$ HEPES, 10 glucose, adjusted to $\mathrm{pH} 7.4$ with $\mathrm{CsOH}$. The internal patch pipette solution contained (in $\mathrm{mM}$ ): 126.5 $\mathrm{CsMeSO}_{4}, 2 \mathrm{MgCl}_{2}, 11$ EGTA, 10 HEPES adjusted to $\mathrm{pH} 7.3$ with $\mathrm{CsOH}$. Internal solution was supplemented with $0.6 \mathrm{mM}$ GTP and $2 \mathrm{mM}$ ATP and mixed thoroughly just prior to use. Liquid junction potentials for above solutions were calculated prior to experiments using pClamp 10 software and corrected for during experiments. Compounds were prepared daily from $30 \mathrm{mM}$ DMSO stocks and diluted into external solution just prior to use. Compounds were then applied rapidly and locally to the cells using a custom-built gravity driven micro- 
perfusion system (Feng, Doering et al. 2003). Initial vehicle experiments were performed to ensure that $0.1 \%$ DMSO had no effect on current amplitudes or channel kinetics (data not shown) and all subsequent experiments contained 0.1\% DMSO in control external solutions. Currents were elicited from a holding potential of $-100 \mathrm{mV}$ and were measured by conventional whole-cell patch clamp techniques using an Axopatch 200B amplifier in combination with Clampex 9.2 software. (Molecular Devices, Sunnyvale, CA). After establishing whole cell configuration, cellular capacitance was minimized using the amplifier's built-in analog compensation. Series resistance was kept to $<10 \mathrm{M} \Omega$ and was compensated to at least $85 \%$ in all experiments. All data were digitized at $10 \mathrm{kHz}$ with a Digidata 1320 interface (Molecular Devices) and filtered at $1 \mathrm{kHz}$ (8-pole Bessel filter). Raw and online leak-subtracted data were both collected simultaneously, P/N4 leak subtraction was performed using opposite polarity and after the protocol sweep. For tonic inhibition of T-type current, membrane potential was stepped from $-100 \mathrm{mV}$ to $-30 \mathrm{mV}$ for $200 \mathrm{~ms}$ and then allowed to recover for 12 seconds (1 sweep). A minimum of 10 sweeps were collected under control external perfusion to allow for control peak current to equilibrate. Drug was then continuously perfused, and sweeps recorded until no further inhibition is seen (minimum of 3 sweeps with same amplitude). In currentvoltage relation studies, the membrane potential was held at $-100 \mathrm{mV}$ and cells were depolarized from -70 to $50 \mathrm{mV}$ in $10 \mathrm{mV}$ increments. For steady-state inactivation studies, a 3.6 second conditioning pre-pulse of various magnitude (initial holding at $-110 \mathrm{mV}$ ), was followed by a depolarizing pulse to $-30 \mathrm{mV}$. Individual sweeps were separated by 12 seconds to permit recovery from inactivation between conditioning pulses. The duration of the test pulse was typically $20 \mathrm{~ms}$ and the current amplitude obtained from each test pulse was normalized to that observed at the holding potential of $-100 \mathrm{mV}$.

\section{Data Analysis and Statistics:}


Data were acquired and analyzed using Clampfit 10.4 (Molecular Devices) and Origin 8.5 software (Northampton, MA, USA) or GraphPad Prism (Version 7.0b, San Diego, CA) was used in the preparation of all figures and curve fittings. Current-voltage (iV) relationships were fitted with a modified Boltzmann equation: $I=[G \max *(V m-E r e v)] /[1+\exp ((\mathrm{V} 0.5 \mathrm{act}-$ $\mathrm{Vm}) / \mathrm{ka}$ )], where $\mathrm{Vm}$ is the test potential, V0.5act is the half-activation potential, Erev is the reversal potential and Gmax is the maximum slope conductance. Steady-state inactivation curves were fitted using Boltzmann equation: $\mathrm{I}=1 /(1+\exp ((\mathrm{Vm}-\mathrm{Vh}) / \mathrm{k}))$, where $\mathrm{Vh}$ is the half-inactivation potential and $\mathrm{k}$ is the slope factor. Dose-response curves were fitted with the equation $\mathrm{y}=\mathrm{A} 2+(\mathrm{A} 1-\mathrm{A} 2) /\left(1+([\mathrm{C}] / \mathrm{IC} 50)^{\mathrm{n}}\right)$ where $\mathrm{A} 1$ is initial current amplitude and $\mathrm{A} 2$ is the current amplitude at saturating drug concentrations, $[\mathrm{C}]$ is the drug concentration and $\mathrm{n}$ is the Hill coefficient. Statistical significance was determined using Student's t-tests and one-way or repeated measures ANOVA. Significant values are indicated in text and figure legends. All data are given as means +/- standard errors. Correlation between FLIPR and Electrophysiology (Ephys) assays was determined as poor when values exceeded $>50 \%$ difference between the two assays. When tonic inhibition of ion channel was greater than $80 \%$ in both assays, compounds were considered to be potent inhibitors of the calcium current and chosen for further testing of kinetic interactions using electrophysiological techniques.

\section{Assay of intracellular calcium concentration (FLIPR assay)}

Changes in intracellular calcium $\left([\mathrm{Ca}]_{\mathrm{i}}\right)$ were measured using a fluorometric imaging plate reader (FLIPR) and using Calcium 5 membrane potential assay kit (Molecular Devices Sunnyvale, CA). Briefly, $24 \mathrm{~h}$ prior to the assay, HEK-3.x cells were detached from the flask using trypsin/EDTA (Sigma-Aldrich) and resuspended in $10 \mathrm{~mL}$ Leibovitz's L-15 media supplemented with $1 \%$ FBS, $100 \mathrm{U}$ penicillin and $100 \mu \mathrm{g}$ streptomycin per mL, $15 \mathrm{mM}$ glucose $2 \mu \mathrm{g} / \mathrm{mL}$ tetracycline. Cells were plated in a volume of $90 \mu \mathrm{L}$ per well in black-walled, clearbottomed 96-well microplates (Corning, Castle Hill, Australia), and incubated overnight at 
$37^{\circ} \mathrm{C}$ in ambient $\mathrm{CO}_{2}$. Dye was reconstituted with assay buffer (HBSS) containing in $\mathrm{mM}$ :

$\mathrm{NaCl} 145, \mathrm{HEPES} 22, \mathrm{Na}_{2} \mathrm{HPO}_{4} 0.338, \mathrm{NaHCO}_{3} 4.17, \mathrm{KH}_{2} \mathrm{PO}_{4} 0.441, \mathrm{MgSO}_{4} 0.407, \mathrm{MgCl}_{2}$

0.493, $\mathrm{CaCl}_{2}$ 1.26, glucose 5.56, pH 7.4, osmolarity 315 mOSM. Cells were loaded with $90 \mu \mathrm{L}$ per well of the dye solution without removal of the L-15 and incubated at $37^{\circ} \mathrm{C}$ for 60 minutes in ambient $\mathrm{CO}_{2}$. Fluorescence was measured using a FlexStation 3 microplate reader (Molecular Devices, excitation $530 \mathrm{~nm} / 565 \mathrm{~nm}$ ). Baseline readings were taken every $2 \mathrm{~s}$ for at least $2 \mathrm{~min}$, at which time drug was added in a volume of $20 \mu \mathrm{L}$ to cells and fluorescence recorded for $5 \mathrm{~min}$ in drug solution. $10 \mathrm{mM} \mathrm{CaCl}_{2}$ was then added to activate the calcium channels and the fluorescence was recorded for a further 3 min. Area under the curve was measured and expressed as change in fluorescence elicited by addition of drug versus percentage of peak baseline fluorescence after subtraction of the changes produced by vehicle addition as previously described (Knapman, Santiago et al. 2013). Final concentration of vehicle (DMSO) was not more than $0.1 \%$. Data were expressed as the mean $\pm \mathrm{SEM}$ of at least 5 independent determinations performed in duplicate, unless otherwise stated. Pooled data were fit to a 4-parameter logistic equation in Graphpad PRISM 7 (GraphPad Software, San Diego CA).

\section{Drugs and reagents:}

Stock Drugs were dissolved in DMSO and diluted fresh before each use in external recording solution to give a final vehicle concentration of $0.1 \%$. Synthetic Cannabinoids were synthesised using methods previously described (Parry, Eiblmaier et al. 2007). Cell culture media, buffers, antibiotics, and general chemicals were from Life Technologies, Sigma-Aldrich or InvivoGen (San Diego, CA, USA).

\section{Results}

Initial FLIPR screening of inhibition of T-type currents by Synthetic Cannabinoids 
Inhibition of T-type calcium channels was measured using a Fluorescence Imaging Plate Reader (FLIPR) assay and results expressed as percentage of baseline fluorescence before and after addition of $10 \mu \mathrm{M}$ synthetic cannabinoid receptor agonist. 8 SCRAs showed $>80 \%$ inhibition of the increase in fluorescence produced by addition of $10 \mathrm{mM} \mathrm{Ca}^{2}$ in cells expressing $\mathrm{Ca}_{\mathrm{v}} 3.1$. Similarly, 3 drugs produced $>80 \%$ fluorescence inhibition of signal in cells expressing $\mathrm{Ca}_{\mathrm{v}} 3.2$ and $\mathrm{Ca}_{\mathrm{v}} 3.3$ (Table 1), but only AMB-CHMINACA produced $>80 \%$ fluorescence inhibition of signal across all three T-type channels using the FLIPR assay (Table 1 and Figure 1B).

Initial Electrophysiology screening of tonic inhibition of T-type currents by Synthetic

\section{Cannabinoids}

Tonic inhibition of T-type currents was measured by stepping the cell membrane potential repetitively from $-100 \mathrm{mV}$ to $-30 \mathrm{mV}$ (sweep) to elicit peak current amplitude while applying continuous perfusion of $10 \mu \mathrm{M}$ synthetic cannabinoid until inhibition reached steady state which was deemed to be obtained when no further reduction in current amplitude was observed after 3 successive sweeps (36 seconds). Again, a threshold of $80 \%$ inhibition of the initial current was used to identify a compound as having significant inhibitory effects on the $\mathrm{Ca}_{\mathrm{v}} 3 . \mathrm{x}$ channels. Screening of the 16 SCRAs identified 3 compounds, MDMB-CHMICA, MDMB-CHMINACA and MDMB-FUBICA as potent inhibitors of $\mathrm{Ca}_{\mathrm{v}} 3.1$. For $\mathrm{Ca}_{\mathrm{v}} 3.2$, MDMB-CHMICA and AMB-CHMINACA were potent inhibitors, however none of the drugs produced an inhibition of $\mathrm{Ca}_{\mathrm{v}} 3.3>80 \%$ in these conditions (Table 1 ).

Overall, the correlation between high throughput FLIPR and electrophysiology screening of synthetic cannabinoids was excellent (Figure 1A). Of the sixteen synthetic cannabinoid compounds screened using both methods, only AMB-CHMICA in $\mathrm{Ca}_{\mathrm{v}} 3.1$ and MDMBFUBICA in $\mathrm{Ca}_{\mathrm{v}} 3.2$, did not correlate (Table 1 highlighted in red). In $\mathrm{Ca}_{\mathrm{v}} 3.3$, three 
compounds AMB-PINICA, AMB-CHMINACA and AMB-CHMICA produced significant inhibition of the fluorescence signal in the FLIPR assay, however the Ephys results showed minimal tonic inhibition of current by these 3 compounds (Table 1 highlighted in red). It is important to note that the results of the other 13 synthetic cannabinoids in $\mathrm{Ca}_{\mathrm{v}} 3.3$ showed excellent correlation between the two assays.

Finally, we also tested the two best-known phytocannabinoids, CBD and $\Delta^{9}$-THC, using electrophysiology (Table 1) and they inhibited T-type $I_{\mathrm{Ca}}$ with results in excellent agreement with previous findings (Ross, Napier et al. 2008).

Following on from the preliminary screening, we further examined the effects of the 2 most potent inhibitors of $\mathrm{Ca}_{\mathrm{v}} 3.2$, MDMB-CHMICA and AMB-CHMINACA on the biophysical properties of these channels in vitro. Using a high concentration $(10 \mu \mathrm{M})$ of both MDMBCHMICA and AMB-CHMINACA to measure time course of $\mathrm{Ca}_{\mathrm{v}} 3.2$ current inhibition, results showed both compounds rapidly inhibited $\mathrm{Ca}_{\mathrm{v}} 3.2$ current amplitude. However, during the washout phase, MDMB-CHMICA inhibition was almost completely reversed after 2 min, whereas AMB-CHMINACA achieved only $<30 \%$ reversal of inhibition after 3 min (Figure 2).

To calculate the half maximal inhibitory concentration $\left(\mathrm{IC}_{50}\right)$ of both SCRAs on $\mathrm{Ca}_{\mathrm{v}} 3.2$ in tonic block conditions, concentration-response curves were generated by superfusing one concentration of drug onto an isolated cell and recording the percent inhibition compared to current measured under vehicle perfusion on the same cell. Data were pooled from at least six independent determinations for each drug concentration and fit to a logistic equation (see methods) which yielded $\mathrm{IC}_{50}$ values of $1.5 \pm 0.2 \mu \mathrm{M}$ and $0.74 \pm 0.3 \mu \mathrm{M}$ for MDMBCHMICA \& AMB-CHMINACA respectively (Figure 3). Using the same tonic inhibition protocol, $\Delta^{9}$-THC and CBD produced slightly less than 50\% inhibition at $10 \mu \mathrm{M}$ in the 
screening assay (Table 1), suggesting the two SCs may be up to 10-fold more potent at inhibiting $\mathrm{Ca}_{\mathrm{v}} 3.2$ conductance under these conditions.

Effects of MDMB-CHMICA and AMB-CHMINACA on biophysical properties of $C a_{v} 3.2$

The effects of MDMB-CHMICA and AMB-CHMINACA (1 $\mu \mathrm{M}$ each) on the voltage dependence of $\mathrm{Ca}_{\mathrm{v}} 3.2$ activation and inactivation were studied as described in the Methods. MDMB-CHMICA significantly shifted half-activation potential $\left(\mathrm{V}_{0.5}\right)$ of $\mathrm{Ca}_{\mathrm{v}} 3.2,(-54.8 \pm 1$ $\mathrm{mV}$ vs $-47 \pm 1 \mathrm{mV}$ Control) ( $\mathrm{n}=6$ for all experiments). However, AMB-CHMINACA did not significantly alter $\mathrm{V}_{0.5}(-43 \pm 1 \mathrm{mV}$ vs $-42.1 \pm 1 \mathrm{mV}$ control). Steady state inactivation was not affected by either MDMB-CHMICA (-78.6 $\pm 1 \mathrm{mV}$ vs $-77.1 \pm 2 \mathrm{mV}$ Control) or AMBCHMINACA $-77.1 \pm 1 \mathrm{mV}$ vs $-80.2 \pm 1 \mathrm{mV}$ control) (Figures 4A and 4B). The effects of the synthetic cannabinoids on channel inactivation is in contrast with those of $\Delta^{9}-\mathrm{THC}$ and CBD, which have both been shown to significantly alter this parameter. However for activation kinetics, the significant negative shift by MDMB-CHMICA is similar to the negative shift caused by $\Delta^{9}$-THC, whereas AMB-CHMINACA is similar to CBD in that it does not significantly alter activation (Ross, Napier et al. 2008).

Previously, it has been shown that compounds can preferentially block $\mathrm{Ca}_{\mathrm{v}} 3.2$ when the channels are in a slow-inactivated conformation (Bladen and Zamponi 2012). Therefore, block of $\mathrm{Ca}_{\mathrm{v}} 3.2$ by accumulating slow inactivation was assessed in the presence and absence of MDMB-CHMICA and AMB-CHMINACA $(1 \mu \mathrm{M})$ using a 2-pulse voltage protocol where an initial depolarizing test pulse from $-120 \mathrm{mV}$ to $-30 \mathrm{mV}$ is used to evoke peak current (P1). This is followed by a 10 second pre-conditioning pulse to $-80 \mathrm{mV}$ that removes the fast steady state inactivation, but maintains the channel in a prolonged slow inactivated state. This is then followed by another test pulse from -120 to $-30 \mathrm{mV}(\mathrm{P} 2)$. Any differences in inhibition between P1 and P2 peak current amplitude are considered to be attributed to drug 
preferentially binding while the channel is held in the slow- inactivated conformation. Using this protocol produced a significant increase in inhibition by both MDMB-CHMICA and AMB-CHMINACA with increases from $47 \% \pm 3.9$ to $80 \% \pm 3.2 \& 45 \% \pm 1.8$ to $87 \% \pm 1.2$ respectively, suggesting these drugs preferentially bind while in a slow inactivated state (Figure 5A). Similarly, $\Delta^{9}$-THC and CBD $(10 \mu \mathrm{M})$ inhibition of $\mathrm{Ca}_{\mathrm{v}} 3.2$ was also significantly enhanced (from $43 \% \pm 2.4$ to $71 \% \pm 4$ and $57 \% \pm 5$ to $96 \% \pm 2$ respectively), when channels were held in this conformation (Figure 5B).

Many local anesthetics and anti-epileptic drugs currently used as therapies to target ion channels, exhibit preferential binding and efficacy in a frequency dependent manner (Sheets, Heers et al. 2008). We therefore examined frequency-dependent inhibition of $\mathrm{Ca}_{\mathrm{v}} 3.2$ by MDMB-CHMICA and AMB-CHMINACA at 0.5 and $1 \mathrm{~Hz}$. However, when we evoked currents at 0.5 and $1 \mathrm{~Hz}$, neither drug showed any significant change in the rate of inhibition vs vehicle control. (Figure 6A). In contrast, $\Delta^{9}$-THC showed a significant increase in inhibition at both 0.5 and $1 \mathrm{~Hz}$ vs vehicle control, whereas CBD showed no increase in inhibition (Figure 6B).

\section{Discussion}

The principal finding of this study is that synthetic cannabinoids MDMB-CHMICA and AMB-CHMINACA potently modulated T-type $I_{\mathrm{Ca}}$ in both a tonic and state dependent manner. MDMB-CHMICA and AMB-CHMINACA effects on $\mathrm{Ca}_{\mathrm{v}} 3.2$ activity were distinct from each other, and quite different to the effects of the phytocannabinoids $\Delta^{9}$-THC and CBD. In particular, neither MDMB-CHMICA or AMB-CHMINACA altered the voltagedependence of the inactivation of $\mathrm{Ca}_{\mathrm{v}} 3.2$, although they did potentiate the accumulation of slow channel inactivation, which can presumably contribute to the inhibition of channel current. The lack of effect on steady state channel inactivation is in contrast to the effects of 
$\Delta^{9}$-THC, CBD and endocannabinoids, which all produce profound hyperpolarizing shifts in the membrane potential at which $\mathrm{Ca}_{\mathrm{v}} 3.2$ opens (Chemin, Monteil et al. 2001, Ross, Napier et al. 2008, Ross, Gilmore et al. 2009, Gilmore, Heblinski et al. 2012). By contrast, MDMBCHMICA, like $\Delta^{9}$-THC, shifted $\mathrm{Ca}_{\mathrm{v}} 3.2$ activation to more negative potentials, while AMBCHMINACA, like CBD, had no such effect.

Several potential drug interaction sites have been identified on $\mathrm{Ca}_{\mathrm{v}} 3$ channels. A crystal structure of $\mathrm{Ca}_{\mathrm{v}} 3.1$ bound to the non-selective T-channel inhibitor Z944 (Zhao, Huang et al. 2019) showed the drug interacting with structural elements of the pore, as well as regions of the channel between domains II and III - so-called fenestrations, previously implicated in the inhibitory actions of local anaesthetic-like drugs at $\mathrm{Ca}_{\mathrm{v}} 3$ and $\mathrm{Nav}$ channels (Bladen and Zamponi 2012, Martin and Corry 2014). The actions of Z944 are voltage-dependent, but it is not known whether the drug shifts the apparent voltage-dependence of steady state activation or inactivation of the channel, and its inhibitory effects were suggested to involve block of the channel pore by an aromatic moiety (Lee 2014). The block of $\mathrm{Ca}_{\mathrm{v}} 3.2$ in the absence of effects on steady state inactivation by both MDMB-CHMICA and AMB-CHMINACA suggest that they may also interact with the channel pore through their cyclohexyl moiety. The tert-leucine moiety of MDMB-CHMICA resembles the tert-butyl group of Z944, which interacts with the domain II-III fenestration in $\mathrm{Ca}_{\mathrm{v}} 3.1$ (Zhao, Huang et al. 2019). The only difference in structure between MDMB-CHMICA and AMB-CHMINACA is an extra methyl in the tert-leucine moiety of MDMB-CHMICA compared to the valine of AMBCHMINACA. It is tempting to speculate that this slight difference may be responsible for the selective effects of AMB-CHMINACA on channel activation.

Both MDMB-CHMICA and AMB-CHMINACA were widely available unregulated drugs in Europe and the United States and have been associated with thousands of serious intoxications and dozens of deaths (EMCDDA 2017). Both drugs are high efficacy CB1 
agonists relative to $\Delta^{9}$-THC (Sachdev, Vemuri et al. 2019), and prima facie the psychoactive effects of these drugs are likely due to this CB1 activity. CB1 agonist activity drives human use and almost certainly contributes to the toxicity of MDMB-CHMICA, AMB-CHMINACA and related drugs, but the role of $\mathrm{CB} 1$ activation in human intoxication idea remains untested. Intoxication by synthetic cannabinoids is associated with a myriad of symptoms, with many of the effects apparently occurring in the central nervous system. It is reasonable to attribute these to activation of CB1. In humans, the subjective psychological effects of $\Delta^{9}$-THC (Micale, Drago et al. 2019)) are significantly attenuated by the CB1 antagonists rimonabant and TM38837, which provides strong evidence for a contribution of CB1 receptors to the psychoactive responses to moderate doses of a low efficacy CB1 agonist and make it likely that synthetic cannabinoids exert CB1-dependent effects on mood. Similarly, the characteristic $\Delta^{9}$-THC-induced tachycardia observed in humans is blocked by rimonabant and TM38837, (Klumpers, Fridberg et al. 2013) (Micale, Drago et al. 2019) demonstrating a role for $\mathrm{CB} 1$ in alterations of some cardiovascular parameters. The concentration of synthetic cannabinoids detected in the serum of people who present for treatment varies tremendously, but for MDMB-CHMICA concentrations of up to $230 \mathrm{nM}(86-91 \mathrm{ng} / \mathrm{mL})$ have been reported in case series (Backberg, Tworek et al. 2017, Franz, Angerer et al. 2017), which at least raises the potential involvement of synthetic cannabinoid interactions with T-type calcium channels in toxicity. Intriguingly, a unique physiological consequence in humans of pharmacological inhibition of T-type calcium channels with the anti-hypertensive drug mibefradil was bradycardia, which has been reported to be associated with intoxication by MDMB-CHMICA and AMB-CHMINACA in a significant minority of cases (Hill, Najafi et al. 2016, Backberg, Tworek et al. 2017, Hermanns-Clausen, Muller et al. 2018). This is in contrast to the acute effects of $\Delta^{9}$-THC, and also many (but not all) other cases of MDMB-CHMICA and AMBCHMINACA intoxication where tachycardia was a major presentation (Najafi, Dunn et al. 
2016, Backberg, Tworek et al. 2017, Hermanns-Clausen, Muller et al. 2018). T-type Calcium channels and $\mathrm{CB}$ receptors are involved in many aspects of normal function, but the absence of studies in humans that differentiate the effects of modulating either protein in the brain makes it difficult to ascribe any aspects of SC toxicity to modulation of either.

In this study, our initial screening experiments for tonic inhibition of T-type calcium channels with the FLIPR assay was cross validated with the results from manual electrophysiology, the current 'gold standard' drug screening technique. Overall, the correlation between inhibitory activity in the FLIPR and patch clamp assays was excellent, with only one outlier seen in $\mathrm{Ca}_{\mathrm{v}} 3.1$ (AMB-CHMICA) and $\mathrm{Ca}_{\mathrm{v}} 3.2$ (MDMB-FUBICA) (Table 1 and Figure 1A). However, 3 of 16 SCRAs showed potent inhibition in the FLIPR assay of $\mathrm{Ca}_{\mathrm{v}} 3.3$ activity compared to minimal inhibition with electrophysiology. We have not established the reason for this greater discordance between the two assays of $\mathrm{Ca}_{\mathrm{v}} 3.3$, but it may be due to the much slower activation/inactivation kinetics of $\mathrm{Ca}_{\mathrm{v}} 3.3$ compared with $\mathrm{Ca}_{\mathrm{v}} 3.1 / 3.2$, or be a consequence of the protocols we used to measure $\mathrm{Ca}_{\mathrm{v}} 3.3$ current in patch clamp. Developing sub-type selective modulators of T-type calcium channels has proven to be very difficult due to their high sequence homology (Perez-Reyes 2003) but the FLIPR assay was able to quickly identify potent SC modulators of T-type channels and the SCRAs screened here showed some sub-type selectivity as none of the potent inhibitors of $\mathrm{Ca}_{\mathrm{v}} 3.1$ and $\mathrm{Ca}_{\mathrm{v}} 3.2$ showed any significant inhibition of $\mathrm{Ca}_{\mathrm{v}} 3.3$. The FLIPR assay proved to be a useful, rapid technique for preliminary screening of compounds against $\mathrm{Ca}_{\mathrm{v}} 3.1$ and $\mathrm{Ca}_{\mathrm{v}} 3.2$, the T-type calcium channels most regularly implicated in the pathogenesis human disease states.

The study which first characterized $\mathrm{N}$-arachidonoylethanolamine (AEA) modulation of $\mathrm{Ca}_{\mathrm{v}} 3$ channels reported that the synthetic cannabinoids CP 55,940 and WIN 55,212 did not modulate $\mathrm{Ca}_{\mathrm{v}} 3.1$ at $10 \mu \mathrm{M}$, and only $\mathrm{HU}-210(10 \mu \mathrm{M})$, a $\Delta^{9}-\mathrm{THC}$ analogue, had an effect (Chemin, Monteil et al. 2001). However, there are a few drugs that combine cannabinoid 
agonist activity and T-channel antagonist activity, these compounds produce anti-nociception in animal models of acute and neuropathic pain (You, Gadotti et al. 2011). Intriguingly, it has been reported previously that cannabinoids such as NMP-7 and cannabinoid-derived molecules such as NMP332, which block $\mathrm{Ca}_{\mathrm{v}} 3.2$ with $\mathrm{IC}_{50}$ values very similar to MDMBCHMICA and AMB-CHMINACA, can produce potent anti-nociception in animal models of acute and chronic pain (Bladen, McDaniel et al. 2015). Anti-nociception was abolished when experiments were repeated in $\mathrm{Ca}_{\mathrm{v}} 3.2$ knockout animals, confirming the importance of the drug/channel interaction for these effects, and highlighting the potential for pain treatment with cannabinoids that also inhibit $\mathrm{Ca}_{\mathrm{v}} 3$.x channels. However, any future potential for SCRAs to become therapies for $\mathrm{Ca}_{\mathrm{v}} 3.2$ associated diseases, will likely depend on whether their agonist activity on $\mathrm{CB} 1$ receptors can be reduced, whilst maintaining their potency at CB2 and potent modulation of T-type calcium channels. 
bioRxiv preprint doi: https://doi.org/10.1101/2020.07.22.215434; this version posted July 23, 2020. The copyright holder for this preprint

\section{Acknowledgements}

This work was supported by NHMRC Project Grant 1107088 awarded to M.K., and M.C. CB was supported by a Macquarie Research Fellowship and by a Sydney Vital research grant. SM was supported by a Macquarie University Doctoral Scholarship. S.D.B. was supported by NHMRC Project Grant 1161571 and the Lambert Initiative for Cannabinoid Therapeutics, a philanthropically funded research program based at The University of Sydney.

\section{Conflict of Interest}

The authors state no conflict of interest. 


\section{References}

Adamowicz, P. (2016). "Fatal intoxication with synthetic cannabinoid MDMB-CHMICA." Forensic Science International 261: e5-e10.

Babi, M.-A., et al. (2017). "A spicy status: Synthetic cannabinoid (spice) use and new-onset refractory status epilepticus-A case report and review of the literature." SAGE Open Medical Case Reports 5: $2050313 \times 17745206$.

Backberg, M., et al. (2017). "Analytically Confirmed Intoxications Involving MDMB-CHMICA from the STRIDA Project." J Med Toxicol 13(1): 52-60.

Banister, S. D. and M. Connor (2018). "The Chemistry and Pharmacology of Synthetic Cannabinoid Receptor Agonists as New Psychoactive Substances: Origins." Handb Exp Pharmacol.

Banister, S. D., et al. (2016). "Pharmacology of Valinate and tert-Leucinate Synthetic Cannabinoids 5F-AMBICA, 5F-AMB, 5F-ADB, AMB-FUBINACA, MDMB-FUBINACA, MDMB-CHMICA, and Their Analogues." ACS Chem Neurosci 7(9): 1241-1254.

Banister, S. D., et al. (2015). "Pharmacology of Indole and Indazole Synthetic Cannabinoid Designer Drugs AB-FUBINACA, ADB-FUBINACA, AB-PINACA, ADB-PINACA, 5F-AB-PINACA, 5F-ADB-PINACA, ADBICA, and 5F-ADBICA." ACS Chem Neurosci 6(9): 1546-1559.

Bender, K. J., et al. (2012). "Control of firing patterns through modulation of axon initial segment Ttype calcium channels." J Physiol 590(Pt 1): 109-118.

Bladen, C., et al. (2015). "Characterization of novel cannabinoid based T-type calcium channel blockers with analgesic effects." ACS Chem Neurosci 6(2): 277-287.

Bladen, C. and G. W. Zamponi (2012). "Common mechanisms of drug interactions with sodium and T-type calcium channels." Mol Pharmacol 82(3): 481-487.

Bourinet, E., et al. (2005). "Silencing of the Cav3.2 T-type calcium channel gene in sensory neurons demonstrates its major role in nociception." EMBO J 24(2): 315-324.

Chemin, J., et al. (2001). "Direct inhibition of T-type calcium channels by the endogenous cannabinoid anandamide." EMBO J 20(24): 7033-7040.

Choi, S., et al. (2007). "Attenuated pain responses in mice lacking Ca(V)3.2 T-type channels." Genes Brain Behav 6(5): 425-431.

David, L. S., et al. (2010). "Splice-variant changes of the Ca(V)3.2 T-type calcium channel mediate voltage-dependent facilitation and associate with cardiac hypertrophy and development." Channels (Austin) 4(5): 375-389. 
bioRxiv preprint doi: https://doi org/10.1101/2020.07.22 215434: this version posted July 23,2020 . The copyriaht holder for this preprin (which was not certified by peer review) is the author/funder, who has granted bioRxiv a license to display the preprint in perpetuity. It is made available under aCC-BY-NC 4.0 International license.

EMCDDA (2017). Report on the risk assessment of methyl 2-[[1-(cyclohexylmethyl)-1H-indole-3carbonyl]amino]-3,3-dimethylbutanoate (MDMB-CHMICA), European Monitoring Centre for Drugs and Drug Addiction.

Feng, Z. P., et al. (2003). "Determinants of inhibition of transiently expressed voltage-gated calcium channels by omega-conotoxins GVIA and MVIIA." J Biol Chem 278(22): 20171-20178.

Franz, F., et al. (2017). "Phase I metabolism of the highly potent synthetic cannabinoid MDMBCHMICA and detection in human urine samples." Drug Test Anal 9(5): 744-753.

Gilmore, A. J., et al. (2012). "Inhibition of human recombinant T-type calcium channels by Narachidonoyl 5-HT." Br J Pharmacol 167(5): 1076-1088.

Hermanns-Clausen, M., et al. (2018). "Acute side effects after consumption of the new synthetic cannabinoids AB-CHMINACA and MDMB-CHMICA." Clin Toxicol (Phila) 56(6): 404-411.

Heron, S. E., et al. (2007). "Extended spectrum of idiopathic generalized epilepsies associated with CACNA1H functional variants." Ann Neurol 62(6): 560-568.

Hill, S. L., et al. (2016). "Clinical toxicity following analytically confirmed use of the synthetic cannabinoid receptor agonist MDMB-CHMICA. A report from the Identification Of Novel psychoActive substances (IONA) study." Clin Toxicol (Phila) 54(8): 638-643.

Jagodic, M. M., et al. (2008). "Upregulation of the T-type calcium current in small rat sensory neurons after chronic constrictive injury of the sciatic nerve." J Neurophysiol 99(6): 3151-3156.

Kampa, B. M., et al. (2007). "Dendritic mechanisms controlling spike-timing-dependent synaptic plasticity." Trends Neurosci 30(9): 456-463.

Khosravani, H., et al. (2005). "Effects of Cav3.2 channel mutations linked to idiopathic generalized epilepsy." Ann Neurol 57(5): 745-749.

Klumpers, L. E., et al. (2013). "Peripheral selectivity of the novel cannabinoid receptor antagonist TM38837 in healthy subjects." Br J Clin Pharmacol 76(6): 846-857.

Knapman, A., et al. (2013). "A continuous, fluorescence-based assay of mu-opioid receptor activation in AtT-20 cells." J Biomol Screen 18(3): 269-276.

Lee, M. (2014). "Z944: a first in class T-type calcium channel modulator for the treatment of pain." $\underline{\mathrm{J}}$ Peripher Nerv Syst 19 Suppl 2: S11-12.

Longworth, M., et al. (2017). "Synthesis and Pharmacological Profiling of the Metabolites of Synthetic Cannabinoid Drugs APICA, STS-135, ADB-PINACA, and 5F-ADB-PINACA." ACS Chem Neurosci 8(8): 1673-1680. 
bioRxiv preprint doi: https://doi org/10.1101/2020.07.22 215434. this version posted July 23,2020 . The copyriaht holder for this preprin (which was not certified by peer review) is the author/funder, who has granted bioRxiv a license to display the preprint in perpetuity. It is made available under aCC-BY-NC 4.0 International license.

Martin, L. J. and B. Corry (2014). "Locating the route of entry and binding sites of benzocaine and phenytoin in a bacterial voltage gated sodium channel." PLoS Comput Biol 10(7): e1003688.

Micale, V., et al. (2019). "The Cannabinoid CB1 Antagonist TM38837 With Limited Penetrance to the Brain Shows Reduced Fear-Promoting Effects in Mice." Front Pharmacol 10: 207.

Najafi, J., et al. (2016). "Severe clinical toxicity following analytically confirmed use of the synthetic cannabinoid receptor agonist MDMB-CHMICA: a report from the Identification Of Novel psychoActive substance study (IONA)." Clinical Toxicology 54(4): 405-405.

Ono, K. and T. lijima (2010). "Cardiac T-type Ca(2+) channels in the heart." J Mol Cell Cardiol 48(1): 65-70.

Parry, J. J., et al. (2007). "Characterization of somatostatin receptor subtype 2 expression in stably transfected A-427 human cancer cells." Mol Imaging 6(1): 56-67.

Perez-Reyes, E. (2003). "Molecular physiology of low-voltage-activated t-type calcium channels." Physiol Rev 83(1): 117-161.

Ross, H. R., et al. (2009). "Inhibition of human recombinant T-type calcium channels by the endocannabinoid N-arachidonoyl dopamine." Br J Pharmacol 156(5): 740-750.

Ross, H. R., et al. (2008). "Inhibition of recombinant human T-type calcium channels by Delta9tetrahydrocannabinol and cannabidiol." J Biol Chem 283(23): 16124-16134.

Sachdev, S., et al. (2019). "In vitro determination of the CB1 efficacy of illicit synthetic cannabinoids." Br J Pharmacol.

Sheets, P. L., et al. (2008). "Differential block of sensory neuronal voltage-gated sodium channels by lacosamide [(2R)-2-(acetylamino)-N-benzyl-3-methoxypropanamide], lidocaine, and carbamazepine." J Pharmacol Exp Ther 326(1): 89-99.

Tait, R. J., et al. (2016). "A systematic review of adverse events arising from the use of synthetic cannabinoids and their associated treatment." Clinical Toxicology 54(1): 1-13.

Trecki, J., et al. (2015). Synthetic Cannabinoid-Related Illnesses and Deaths.

You, H., et al. (2011). "Functional characterization and analgesic effects of mixed cannabinoid receptor/T-type channel ligands." Mol Pain 7: 89.

Zamponi, G. W., et al. (2010). "Role of voltage-gated calcium channels in epilepsy." Pflugers Arch 460(2): 395-403.

Zhao, Y., et al. (2019). "Cryo-EM structures of apo and antagonist-bound human Cav3.1." Nature 576(7787): 492-497. 


\section{Figure Legends}

Table 1. Initial screening of Synthetic Cannabinoids using Fluorescence Imaging Plate Reader (FLIPR) and Patch Clamp Electrophysiology (Ephys).

Table 1 shows results of 16 synthetic cannabinoids screened at $10 \mu \mathrm{M}$ with both FLIPR and Ephys assays on stably expressed human T-type calcium channels in HEK293T Cells $\left(\mathrm{hCa}_{\mathrm{v}}\right.$ $3.1, \mathrm{hCa}_{\mathrm{v}} 3.2$ and $\mathrm{hCa}_{\mathrm{v}} 3.3$ ). Compounds that produced greater than $80 \%$ fluorescence (FLIPR) or current inhibition (Ephys) at this concentration were designated as potent and highlighted in green. FLIPR identified 8 SCRAs that inhibited fluorescence $>80 \%$ in $\mathrm{hCa}_{\mathrm{v}}$ 3.,1 however Ephys produced only 1, MDMB-CHMINACA. In $\mathrm{hCa}_{\mathrm{v}} 3.2$, FLIPR identified three compounds MDMB-CHMICA, MDMB-FUBICA and AMB-CHMINACA as potent fluorescence inhibitors in $\mathrm{hCa}_{\mathrm{v}} 3.2$ while Ephys confirmed two of those compounds, MDMBCHMICA and AMB-CHMINACA as potent current blockers. In $\mathrm{hCa}_{\mathrm{v}} 3.3$, FLIPR identified 3 SCRAs that showed $>80 \%$ fluorescence inhibition, however in the Ephys assay, none of the SC compounds showed any significant block. Variance of greater than $50 \%$ between the FLIPR and Ephys assays are highlighted in red and Ephys data for phytocannabinoids' THC and CBD are shown for reference purposes. Data are \% fluorescence or current inhibition and represent the mean \pm SEM of 6 independent FLIPR assays per compound on each stably expressed ion channel or the mean \pm SEM of 6 independent whole-cell patch clamp recordings per compound on each channel.

\section{Figure 1. Comparison of Fluorescence Imaging Plate Reader (FLIPR) screening of Synthetic Cannabinoids to Patch Clamp Electrophysiology.}

1A. Results of the FLIPR assay (X axis) were plotted against the results of the Ephys assay ( $Y$ axis) and a linear regression analysis performed between the 2 sets of data. Overall, the correlation between synthetic cannabinoid screening $(10 \mu \mathrm{M})$ with FLIPR and Ephys assays on all 3 stably expressed human T-type calcium channels was excellent with $\mathrm{R}$ values of $0.66,0.30$ and 0.32 and $P$ values of $0.0001,0.030$ and 0.023 for $h C a_{v} 3.1, h_{C a} 3.2$ and $h \mathrm{hCa}_{\mathrm{v}}$ 3.3 respectively. Of the sixteen SCRAs tested, only AMB-CHMICA in hCa 3.1 and MDMBFUBICA in $\mathrm{hCa}_{\mathrm{v}} 3.2$ had a variance of greater than $50 \%$ between the two assays (also highlighted red in Table 1). In addition, when screening $\mathrm{hCa}_{\mathrm{v}} 3.3$, the FLIPR assay identified 3 compounds as potent inhibitors, however none of the SCRAs showed any significant block in the Ephys assay. 1B. Results of the FLIPR data for AMB-CHMINACA are shown since this was the only compound to show potent $\%$ fluorescence inhibition across all three T-type calcium channels.

\section{Figure 2. Representative time course of $h C a_{v} 3.2$ current inhibition by MDMB- CHMICA and AMB-CHMINACA}

Using the same step voltage protocol (inset) and same drug concentration $(10 \mu \mathrm{M})$ as the Ephys screening assay, time course of $\mathrm{hCa}_{\mathrm{v}} 3.2$ inhibition was recorded followed by washout. Both drugs rapidly blocked hCa 3.2 , however MDMB-CHMICA (Red) block was almost completely reversed on washout whereas AMB-CHMINACA (Blue) washout was $<30 \%$. Right panels are current traces from the endpoint of control, drug and wash.

\section{Figure 3. hCa 3.2 Dose Response Curves (IC50) of MDMB-CHMICA and AMB- CHMINACA}


Dose-response curves were generated using Log concentrations of MDMB-CHMICA (Red) \& AMB-CHMINACA (Blue) and fitted with Boltsmann iV equation to yield $\mathrm{IC}_{50}$ of $1.5 \pm$ $0.2 \& 0.74 \pm 0.3 \mu \mathrm{M}$ respectively (Current inhibition was normalised to vehicle control and represent the mean \pm SEM of 6 independent cellular recordings)

\section{Figure 4. hCav 3.2 Activation and Inactivation kinetics of MDMB-CHMICA and AMB-} CHMINACA

4A. Using a current-voltage relationship protocol (iV), $1 \mu$ M MDMB-CHMICA significantly shifted half-activation potential (vo.5) of hCav3.2 $(-54.8 \pm 1 \mathrm{mV}$ vs $-47 \pm 1 \mathrm{mV}$ Control) (Red open circles). However, Steady State Inactivation (SSI) was not affected (-78.6 $\pm 1 \mathrm{mV}$ vs $-77.1 \pm 2 \mathrm{mV}$ Control) (Red closed circles). 4B. Using the same protocols, $1 \mu \mathrm{M}$ AMB-CHMINACA did not significantly alter vo.5 $(-43 \pm 1 \mathrm{mV}$ vs $-42.1 \pm 1 \mathrm{mV}$ Control $)$ (Blue open circles) or SSI (-77.1 $\pm 1 \mathrm{mV}$ vs $-80.2 \pm 1 \mathrm{mV}$ Control) (Blue closed circles). Results are normalised to peak current and represent the mean \pm SEM of 6 independent cellular recordings).

Figure 5. hCav 3.2 current inhibition in slow inactivated state by MDMB-CHMICA, AMB-CHMINACA, THC and CBD

5A. A 2-pulse voltage protocol (Inset) was used to elicit $\mathrm{hCa}_{\mathrm{v}} 3.2$ into a slow inactivation state. This produced a dramatic increase in current inhibition by both MDMB-CHMICA \& AMB-CHMINACA at $1 \mu \mathrm{M}$. For MDMB-CHMICA, current inhibition increased from $47 \pm$ $3.9 \%$ tonic (P1), to $80 \pm 3.2 \%$ in slow inactivated state (P2) and for AMB-CHMINACA, from $45 \pm 1.8$ to $87 \pm 1.1 \%$. 5B. For THC, current inhibition increased from $43 \pm 2.4 \%$ tonic $(\mathrm{P} 1)$, to $71 \pm 3.7 \%$ in slow inactivated state $(\mathrm{P} 2)$ and for $\mathrm{CBD}$, inhibition increased from $57 \pm$ $5 \%$ tonic $(\mathrm{P} 1)$, to $96 \pm 1.8 \%$ in slow inactivated state $(\mathrm{P} 2)$. Representative traces from $\mathrm{P} 1 \mathrm{vs}$ $\mathrm{P} 2$ for each drug are shown inset. Results are represented as percent inhibition of peak current of vehicle control and represent the mean \pm SEM of 6 independent cellular recordings.

Statistical analysis was performed using Student t-test with asterisks denoting significance at ${ }^{*} \mathrm{p}<0.05, * * \mathrm{p}<0.01, * * * \mathrm{p}<0.001$

\section{Figure 6. hCa 3.2 Frequency dependent block of MDMB-CHMICA, AMB- CHMINACA, THC and CBD}

6A. Cells were held at $-100 \mathrm{mV}$ and stepped to- $30 \mathrm{mV}$ for 2 different frequencies ( 1 and 0.5 $\mathrm{Hz}$ ), with inter-sweep holding potential of $-100 \mathrm{mV}$. Peak currents from each sweep were normalized to the average peak current of first three sweeps and plotted against sweep number. Black symbols represent control vehicle without drugs, while red and blue symbols represent experiments in the presence of $1 \mu \mathrm{M}$ MDMB-CHMICA and AMB-CHMINACA, respectively. Bar graphs represent the relative amplitudes of the average of the last 3 sweeps for each frequency. At 0.5 and $1 \mathrm{~Hz}$ ( 2 and 1 second inter-sweep intervals), neither drug showed significant difference from control. 6B. At $10 \mu \mathrm{M}$, THC but not CBD, showed a significant increase in frequency dependent inhibition after 40 sweeps. At $0.5 \mathrm{~Hz}$ and $1 \mathrm{~Hz}$, inhibition increased $18.2 \pm 0.4 \%$ and $20.8 \pm 0.3 \%$ respectively. Statistical analysis was performed using Student t-test with asterisks denoting significance at $* \mathrm{p}<0.05$. 
Bladen et al., Table 1

\begin{tabular}{|c|c|c|c|c|c|c|c|c|c|}
\hline & Structur & subunits & & FLIPR & Ephys & FLIPR & Ephys & FLIPR & Ephys \\
\hline Compound Name & Core & Alkyl chain & Amino acid & $\mathrm{Ca}_{\mathrm{v}} \mathrm{3.1}$ & $\mathrm{Ca}_{\mathrm{v}} \mathbf{3 . 1}$ & $\mathrm{Ca}_{\mathrm{v}} 3.2$ & $\mathrm{Ca}_{\mathrm{v}} 3.2$ & $\mathrm{Ca}_{\mathrm{v}} 3.3$ & $\mathrm{Ca}_{\mathrm{v}} \mathrm{3.3}$ \\
\hline АМВ-СНМICA & Indole & $\begin{array}{l}\text { (Cyclohexyl) } \\
\text { methyl }\end{array}$ & Valinate & $\begin{array}{l}81.8 \pm \\
2.8 \\
\end{array}$ & $\begin{array}{l}27.3 \pm \\
1.17 \\
\end{array}$ & $\begin{array}{l}72.3 \pm \\
1.2\end{array}$ & $\begin{array}{l}56.3 \pm \\
7.9 \\
\end{array}$ & $\begin{array}{l}85.5 \pm \\
1.4 \\
\end{array}$ & $\begin{array}{l}21.5 \pm \\
2.9 \\
\end{array}$ \\
\hline MDMB CHMICA & Indole & $\begin{array}{l}\text { (Cyclohexyl) } \\
\text { methyl }\end{array}$ & t-Leucinate & $\begin{array}{l}85.8 \pm \\
1.1 \\
\end{array}$ & $\begin{array}{l}78.0 \pm \\
3.2 \\
\end{array}$ & $\begin{array}{l}89.7 \pm \\
1.0 \\
\end{array}$ & $\begin{array}{l}89.9 \pm \\
1.7 \\
\end{array}$ & $\begin{array}{l}60.1 \pm \\
5.7 \\
\end{array}$ & $\begin{array}{l}36.0 \pm \\
2.1 \\
\end{array}$ \\
\hline AMB-CHMINACA & Indazole & $\begin{array}{l}\text { (Cyclohexyl) } \\
\text { methyl }\end{array}$ & Valinate & $\begin{array}{l}91.3 \pm \\
1.1\end{array}$ & $\begin{array}{l}64.2 \pm \\
5.0\end{array}$ & $\begin{array}{l}83.3 \pm \\
0.6\end{array}$ & $\begin{array}{l}81.0 \pm \\
3.7\end{array}$ & $\begin{array}{l}94.1 \pm \\
0.6\end{array}$ & $\begin{array}{l}29.9 \pm \\
1.5\end{array}$ \\
\hline MDMB-CHMINACA & Indazole & $\begin{array}{l}\text { (Cyclohexyl) } \\
\text { methyl }\end{array}$ & t-Leucinate & $\begin{array}{l}75.1 \pm \\
5.4 \\
\end{array}$ & $\begin{array}{l}80.8 \pm \\
0.9\end{array}$ & $\begin{array}{l}56.8 \pm \\
3.3 \\
\end{array}$ & $\begin{array}{l}61.3 \pm \\
7.1 \\
\end{array}$ & $\begin{array}{l}33.7 \pm \\
6.9 \\
\end{array}$ & $\begin{array}{l}41.3 \pm \\
5.4 \\
\end{array}$ \\
\hline AMB-FUBICA & Indole & $\begin{array}{l}\text { 4- } \\
\text { Fluorobenzyl }\end{array}$ & Valinate & $\begin{array}{l}41.3 \pm \\
3.6\end{array}$ & $\begin{array}{l}46.4 \pm \\
1.6\end{array}$ & $\begin{array}{l}\text { 53.9 } \pm \\
0.7\end{array}$ & $\begin{array}{l}47.6 \pm \\
8.6\end{array}$ & $\begin{array}{l}6.1 \pm \\
1.1\end{array}$ & $\begin{array}{l}10.6 \pm \\
3.6\end{array}$ \\
\hline MDMB-FUBICA & Indole & $\begin{array}{l}\text { 4- } \\
\text { Fluorobenzyl }\end{array}$ & t-Leucinate & $\begin{array}{l}95.8 \pm \\
0.8\end{array}$ & $\begin{array}{l}77.7 \pm \\
3.7\end{array}$ & $\begin{array}{l}94.7 \pm \\
0.5\end{array}$ & $\begin{array}{l}32.8 \pm \\
8.4\end{array}$ & $\begin{array}{l}52.8 \pm \\
5.2\end{array}$ & $\begin{array}{l}30.8 \pm \\
4.0\end{array}$ \\
\hline AMB-FUBINACA & Indazole & $\begin{array}{l}\text { 4- } \\
\text { Fluorobenzyl }\end{array}$ & Valinate & $\begin{array}{l}92.2 \pm \\
2.3\end{array}$ & $\begin{array}{l}\text { 61.8 } \pm \\
3.9\end{array}$ & $\begin{array}{l}69.6 \pm \\
0.5\end{array}$ & $54.9 \pm 9$ & $\begin{array}{l}18.2 \pm \\
1.3\end{array}$ & $\begin{array}{l}2.6 \pm \\
0.6\end{array}$ \\
\hline MDMB FUBINACA & Indazole & $\begin{array}{l}4- \\
\text { Fluorobenzyl }\end{array}$ & t-Leucinate & $\begin{array}{l}38.0 \pm \\
1.3\end{array}$ & $\begin{array}{l}46.8 \pm \\
3.9\end{array}$ & $\begin{array}{l}68.2 \pm \\
1.3\end{array}$ & $\begin{array}{l}45.3 \pm \\
5.7\end{array}$ & $\begin{array}{l}.8 \pm \\
3.7\end{array}$ & $\begin{array}{l}33.1 \pm \\
5.4\end{array}$ \\
\hline AMB-PICA & Indole & Pentyl & Valinate & $\begin{array}{l}38.3 \pm \\
2.5 \\
\end{array}$ & $\begin{array}{l}28.0 \pm \\
5.8\end{array}$ & $\begin{array}{l}15.8 \pm \\
5.6\end{array}$ & $\begin{array}{l}35.1 \pm \\
7.3\end{array}$ & $\begin{array}{l}13.4 \pm \\
2.4\end{array}$ & $\begin{array}{l}13.3 \pm \\
4.1 \\
\end{array}$ \\
\hline MDMB PICA & Indole & Pentyl & t-Leucinate & $\begin{array}{l}5.5 \pm \\
1.7\end{array}$ & $\begin{array}{l}13.6 \pm \\
2.2\end{array}$ & $\begin{array}{l}58.5 \pm \\
2.9\end{array}$ & $\begin{array}{l}40.3 \pm \\
6.5\end{array}$ & $\begin{array}{l}8.7 \pm \\
2.0\end{array}$ & $\begin{array}{l}6.7 \pm \\
2.2\end{array}$ \\
\hline AMB-PINACA & Indazole & Pentyl & Valinate & $\begin{array}{l}95.3 \pm \\
0.9 \\
\end{array}$ & $\begin{array}{l}54.5 \pm \\
2.6 \\
\end{array}$ & $\begin{array}{l}83.7 \pm \\
1.2 \\
\end{array}$ & $\begin{array}{l}45.9 \pm \\
3.4 \\
\end{array}$ & $\begin{array}{l}95.5 \pm \\
1.1 \\
\end{array}$ & $\begin{array}{l}26.9 \pm \\
2.0 \\
\end{array}$ \\
\hline MDMB-PINACA & Indazole & Pentyl & t-Leucinate & $\begin{array}{l}92.7 \pm \\
2.4 \\
\end{array}$ & $\begin{array}{l}67.8 \pm \\
5.5 \\
\end{array}$ & $\begin{array}{l}59.6 \pm \\
3.3 \\
\end{array}$ & $\begin{array}{l}46.1 \pm \\
9.5 \\
\end{array}$ & $\begin{array}{l}\mathbf{5 5 . 4} \pm \\
\mathbf{7 . 8} \\
\end{array}$ & $\begin{array}{l}38.0 \pm \\
4.0\end{array}$ \\
\hline 5F-AMB-PICA & Indole & $\begin{array}{l}5- \\
\text { Fluoropentyl }\end{array}$ & Valinate & $\begin{array}{l}14.4 \pm \\
2.4\end{array}$ & $\begin{array}{l}12.1 \pm \\
1.9\end{array}$ & $\begin{array}{l}13.5 \pm \\
3.6\end{array}$ & $\begin{array}{l}22.5 \pm \\
3.5\end{array}$ & $\begin{array}{l}10.8 \pm \\
1.9\end{array}$ & $2.1 \pm 0.8$ \\
\hline 5F-MDMB-PICA & Indole & $\begin{array}{l}5- \\
\text { Fluoropentyl }\end{array}$ & t-Leucinate & $\begin{array}{l}51.4 \\
\pm 1.4\end{array}$ & $\begin{array}{l}42.6 \pm \\
2.1\end{array}$ & $\begin{array}{l}66.3 \pm \\
1.5\end{array}$ & $\begin{array}{l}48.5 \pm \\
0.8\end{array}$ & $\begin{array}{l}11.9 \pm \\
3.7\end{array}$ & $\begin{array}{l}8.1 \pm \\
2.1\end{array}$ \\
\hline 5F-AMB-PINACA & Indazole & $\begin{array}{l}\text { 5- } \\
\text { Fluoropentyl } \\
\end{array}$ & Valinate & $\begin{array}{l}28.8 \pm \\
6.0 \\
\end{array}$ & $\begin{array}{l}27.6 \pm \\
2.8 \\
\end{array}$ & $\begin{array}{l}13.5 \pm \\
3.6 \\
\end{array}$ & $\begin{array}{l}44.1 \pm \\
9.5 \\
\end{array}$ & $\begin{array}{l}4.2 \pm \\
4.2 \\
\end{array}$ & $\begin{array}{l}2.2 \pm \\
0.5 \\
\end{array}$ \\
\hline $\begin{array}{l}\text { 5F-MDMB-PINACA } \\
\text { (5F-ADB) } \\
\end{array}$ & Indazole & $\begin{array}{l}5- \\
\text { Fluoropentyl } \\
\end{array}$ & t-Leucinate & $\begin{array}{l}81.4 \pm \\
0.6 \\
\end{array}$ & $\begin{array}{l}67.6 \pm \\
1.6 \\
\end{array}$ & $\begin{array}{l}56.8 \pm \\
1.5 \\
\end{array}$ & $\begin{array}{l}43.5 \pm \\
1.8 \\
\end{array}$ & $\begin{array}{l}24.0 \pm \\
3.8 \\
\end{array}$ & $\begin{array}{l}24.0 \pm \\
3.5 \\
\end{array}$ \\
\hline $\begin{array}{l}\Delta^{9}- \\
\text { tetrahydrocannabinol }\end{array}$ & - & - & - & & $\begin{array}{l}74.9 \pm \\
3.9\end{array}$ & & $\begin{array}{l}43.4 \pm \\
5.5\end{array}$ & & $\begin{array}{l}6.4 \pm \\
3.1 \\
\end{array}$ \\
\hline Cannabidiol & - & - & - & & $\begin{array}{l}69.5 \pm \\
4.0 \\
\end{array}$ & & $\begin{array}{l}48.0 \pm \\
5.2 \\
\end{array}$ & & $\begin{array}{l}31.6 \pm \\
4.8 \\
\end{array}$ \\
\hline
\end{tabular}


bioRxiv preprint doi: https://doi.org/10.1101/2020 07.22.215434 this version posted July 23,2020 . The copyright holder for this preprin

Bladen et al., Figure 1
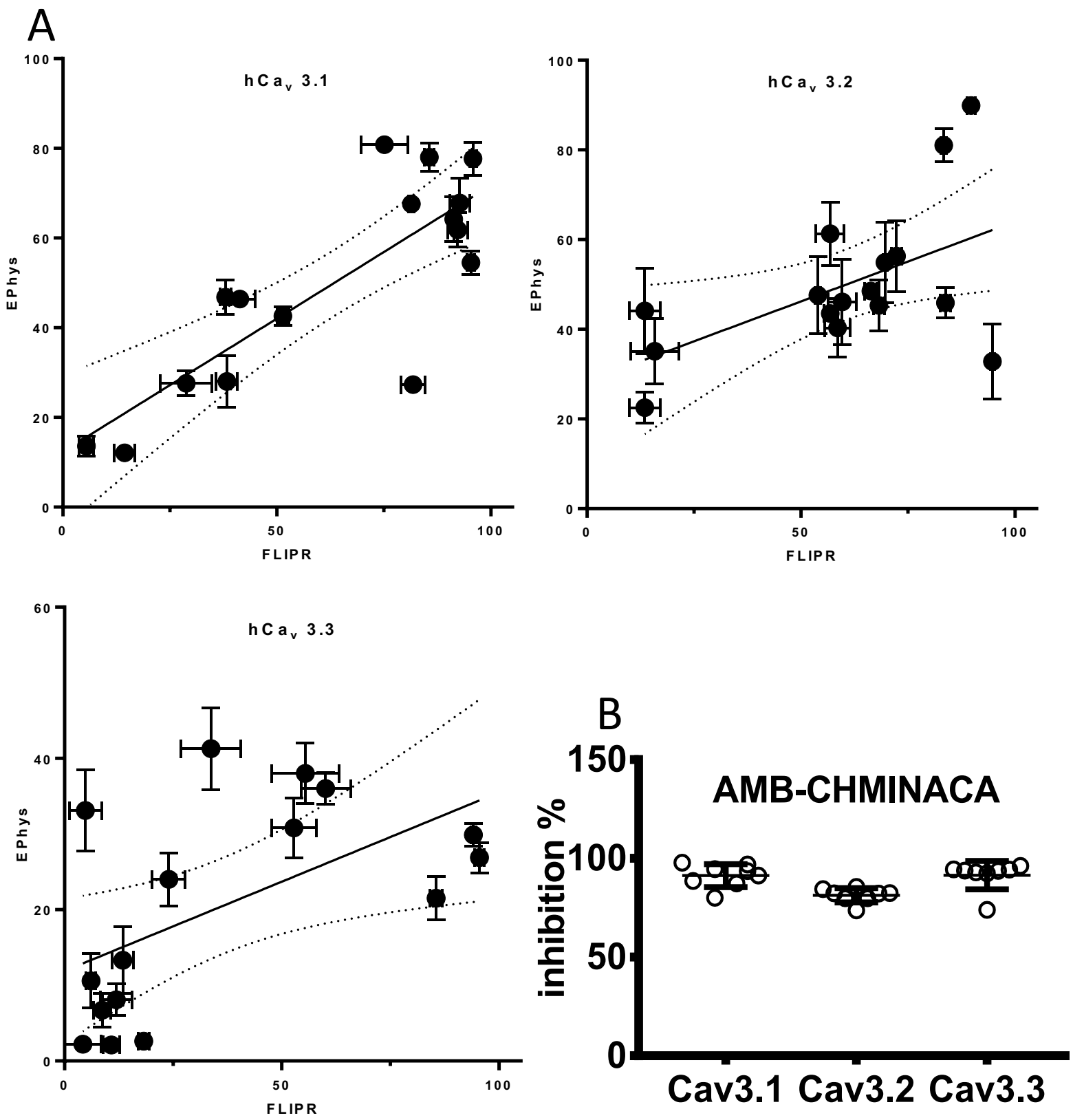
Bladen et al., Figure 2
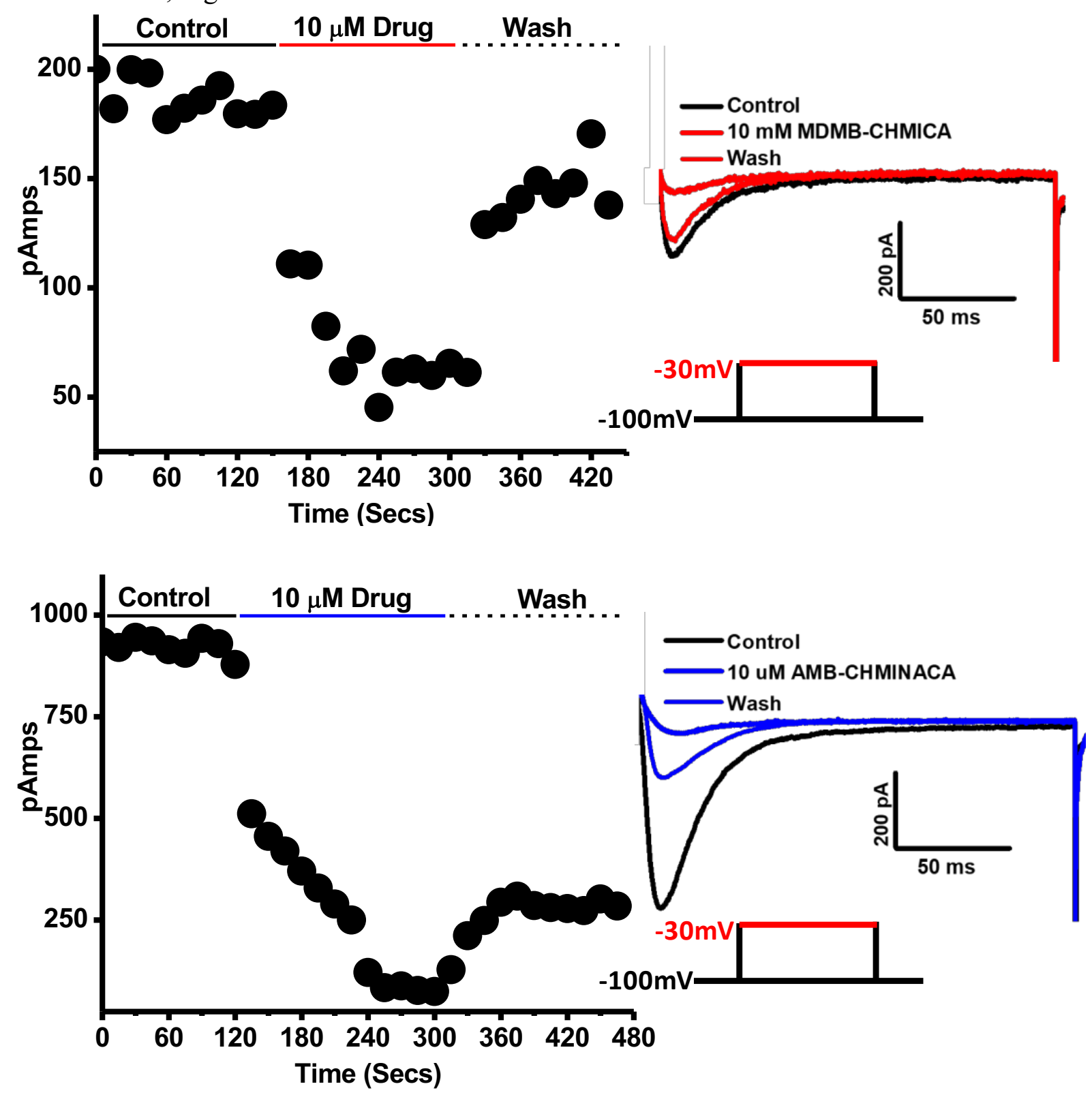
bioRxiv preprint doi: https://doi.org/10.1101/2020.07.22.215434; this version posted July 23, 2020. The copyright holder for this preprint (which was not certified by peer review) is the author/funder, who has granted bioRxiv a license to display the preprint in perpetuity. It is made available under aCC-BY-NC 4.0 International license.

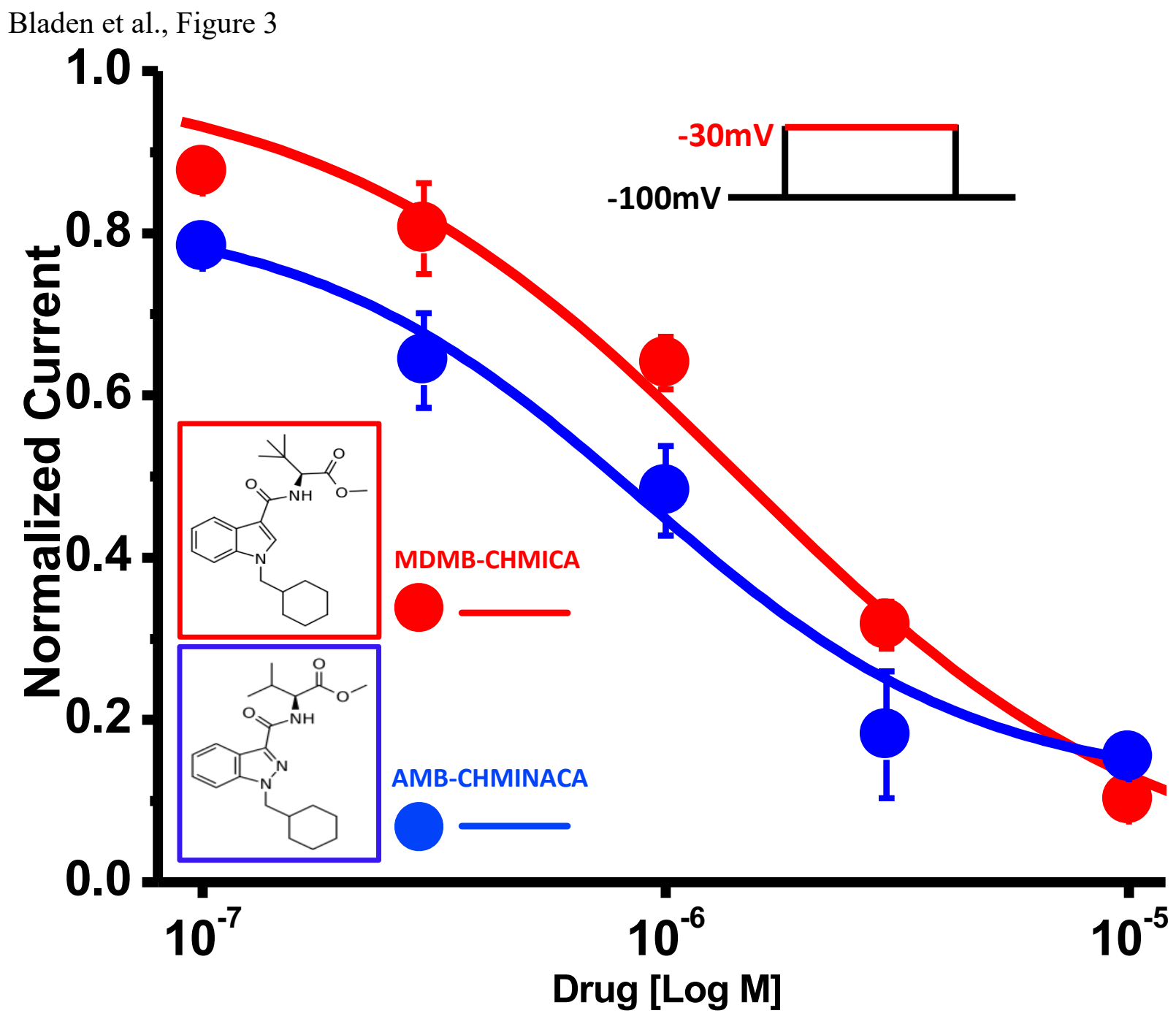


Bladen et al., Figure 4
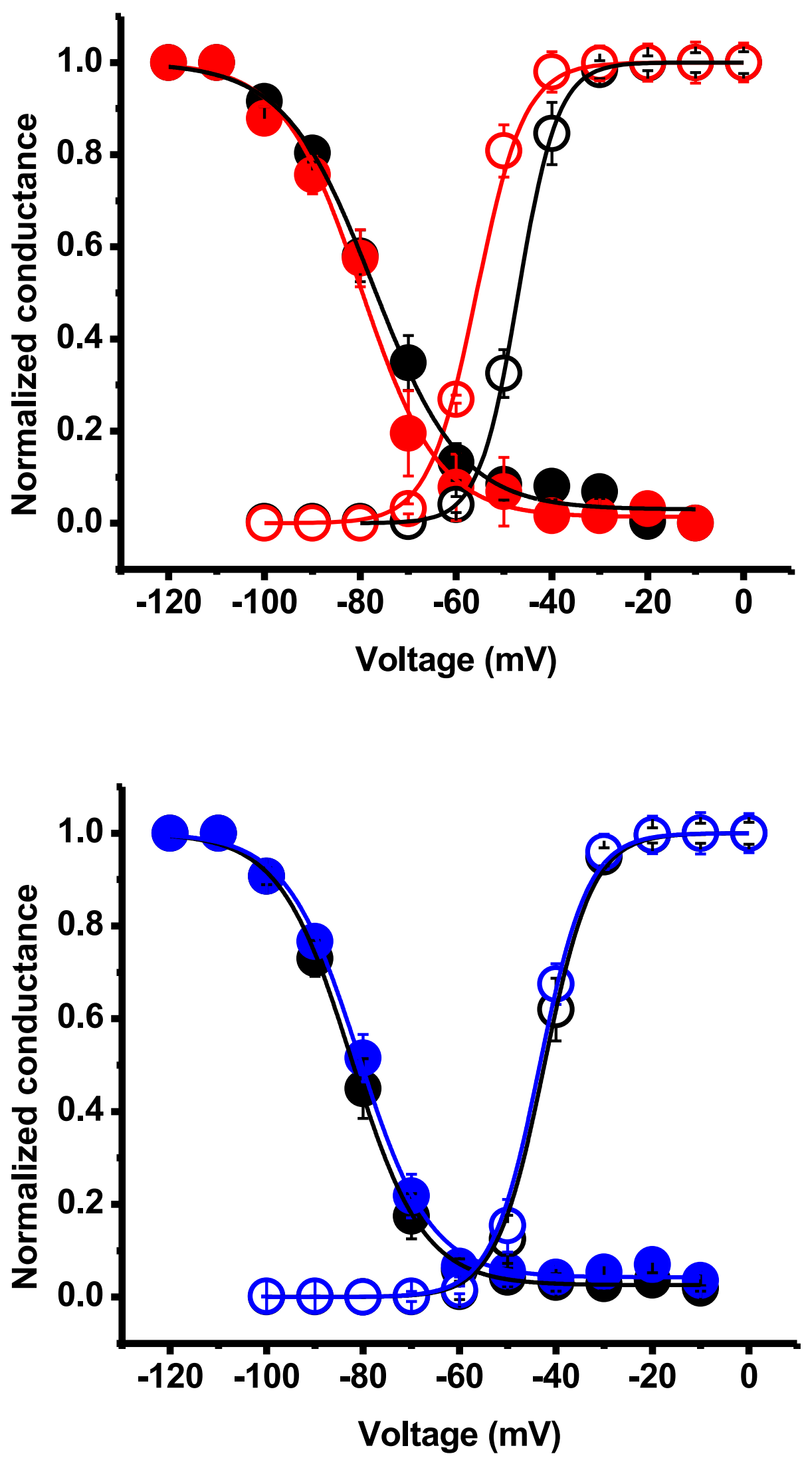
bioRxiv preprint doi: https://doi.org/10.1101/2020.07 22 215434 this version posted July 23,2020 . The copyriaht holder for this preprin

Bladen et al., Figure 5
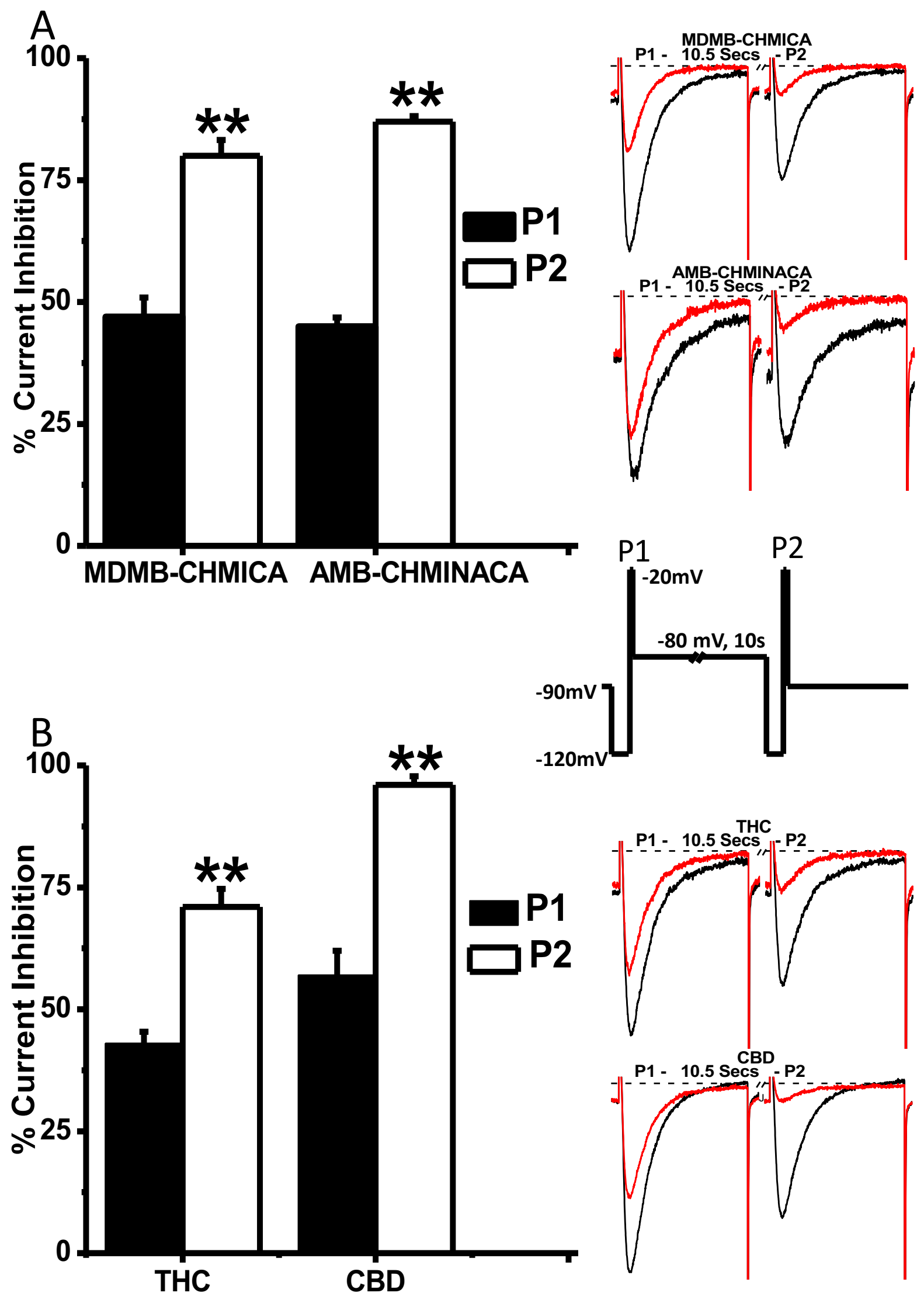
Bladen et al., Figure 6
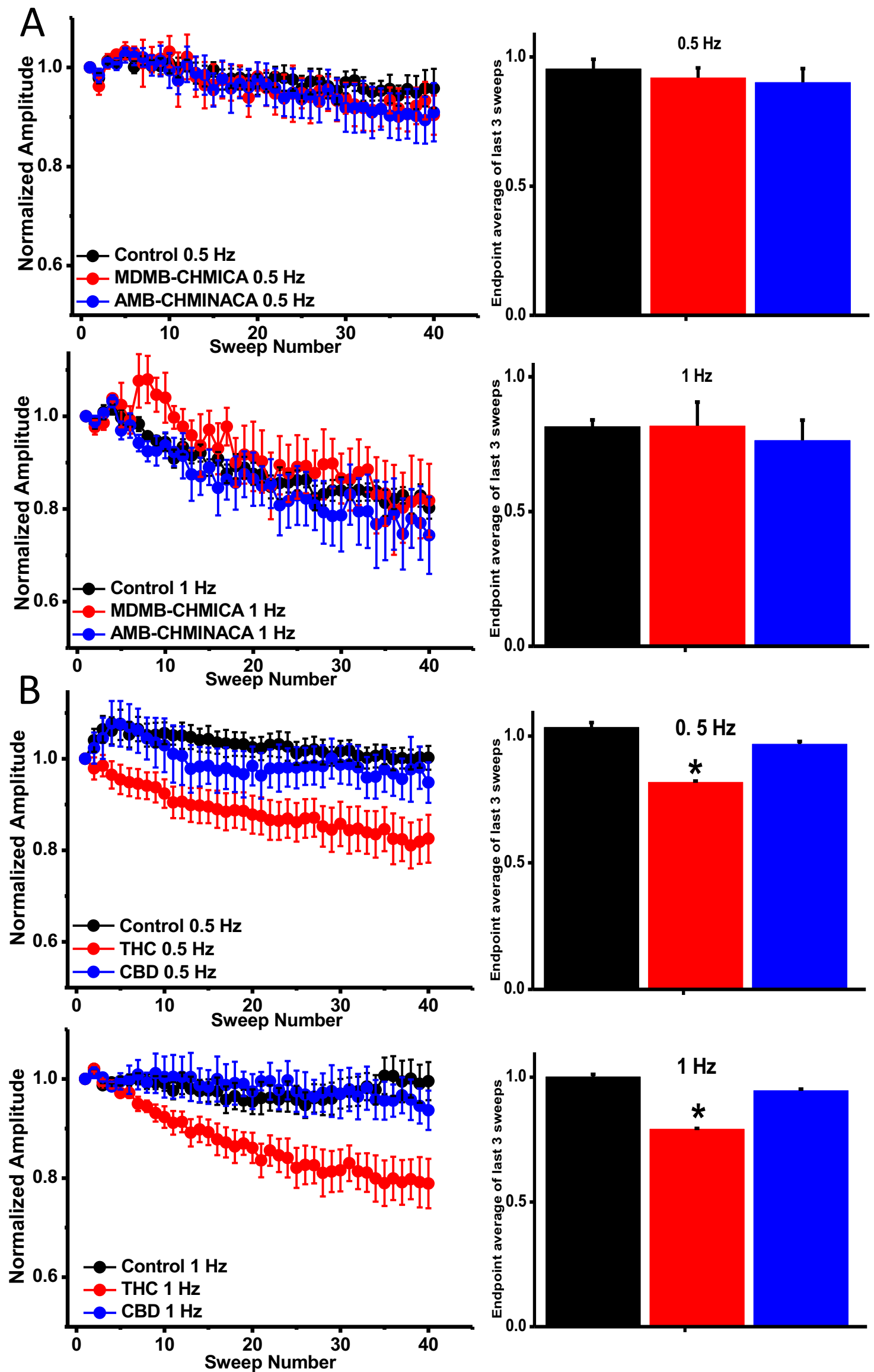